\title{
Raymond Gosling: the man who crystallized genes
}

Naomi Attar*

\section{Abstract \\ On April 25th 1953, three publications in Nature forever changed the face of the life sciences in reporting the structure of DNA. Sixty years later, Raymond Gosling shares his memories of the race to the double helix.}

It has not escaped our attention that the specific pairing we have postulated immediately suggests a possible copying mechanism for the genetic material.

James D Watson and Francis HC Crick [1]

By including this statement in their April 25th 1953 Nature article describing a model for the structure of DNA, Watson and Crick made one of the great understatements in history. In that moment, the seeds for the double helix's infamy - alongside the names 'Watson' and Crick' - were sown. Lesser known outside scientific circles is that this article did not include one iota of experimental data: Watson and Crick, who were based at the University of Cambridge's Cavendish laboratory, contributed deductive reasoning alone to the double helix model, albeit reasoning of an undoubtedly Nobel Prizeworthy standard. Instead, as has now been described many times, the model relied on X-ray diffraction data obtained by others, at King's College, and these data did not reach Watson and Crick by entirely wholesome means [2]. To add to the insult, Watson and Crick's report of the double helix did not fully credit the work of King's as being essential to the construction of their model, although the King's team did enjoy co-publication of their data alongside the double helix article, in the form of two articles in the same issue of Nature [3,4]. One of these articles described the X-ray diffraction work performed by senior researcher Rosalind E Franklin, together with PhD student Raymond G Gosling, and contained the highest quality diffraction patterns yet achieved for DNA [3]. It was these data that had proved

*Correspondence: naomi.attar@genomebiology.com Genome Biology, BioMed Central, 236 Gray's Inn Road, London WC1X 8HB, UK invaluable in Watson and Crick's quest for the double helix.

Earlier still, before Franklin arrived at King's, Gosling had achieved a major breakthrough in the search for DNA's structure when he became the first person to crystallize genes, under the guidance of Maurice Wilkins, who was the lead author of the other King's article to accompany Watson and Crick's model [4].

Watson published his controversial memoir of the discovery, aptly named 'The Double Helix', in the 1960s [5], and in doing so propelled the story to worldwide fame, establishing DNA's structure as an icon of science in the popular imagination. However, events were relayed in Watson's book very much from his own point of view and at times, it has been argued, even verged on the fictitious.

Aside from Watson, Ray Gosling is the only surviving member of the select group of seven scientists to feature as an author on one of the three Nature articles. Gosling and his wife, Mary, were kind enough to welcome Genome Biology into their home, where he shared with us his perspective of the events of 60 years ago.

Elsewhere, Genome Biology has marked the anniversary by canvassing our Editorial Board for their opinions on the most important advances in the field since 1953 [6].

\section{The accidental biophysicist}

Something curious happened in scientific research in the mid-20th Century. Biology had been the neglected sibling of chemistry and, especially, physics, which had until then monopolized the glitz and glamor of scientific inquiry. Perhaps it was the sense that many of the big questions in physics had now been tackled, or a philosophical shift brought about by the experience of the dark forces of war and fascism in the 1930s and 40s, or perhaps it was just a simple matter of improved methodology; whatever the cause, history shows that many physicists and chemists began to become excited by biology at this time, and to turn their attention to addressing biological questions. Nobel Prize-winning physicist Erwin Schrödinger is often credited with kick-starting this trend in his book 'What is life?' [7], which is said to have inspired even Crick and Watson themselves in their quest for the double helix.

So was Prof (Emeritus) Raymond Gosling DSc FKC (Figure 1) similarly inspired when he opted to pursue a 


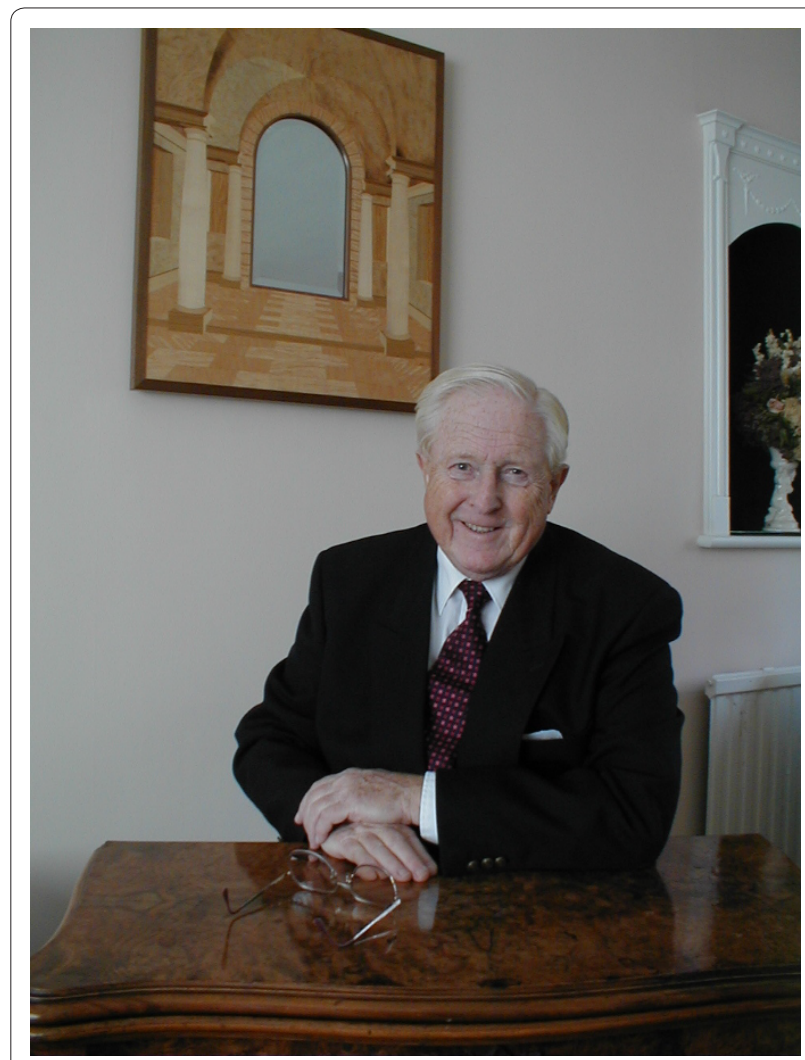

Figure 1. Prof (Emeritus) Raymond Gosling DSc FKC. A portrait of Ray Gosling. @ Raymond Gosling; reproduced with permission.

PhD in biophysics, in work that would culminate in establishing the molecular structure of DNA? Not a bit of it! Not only was Gosling unaware of Schrödinger's work until "much later", he had not in fact originally wanted to become a scientist at all: "I wanted to do Medicine, but Father said we couldn't afford Medicine because it would take $x$ years to qualify and so on. And so the next best thing to doing medicine I thought was to do a fundamental subject like physics. I was very attracted by the thought that the Scots always refer to physics as 'natural philosophy.'

And so a career in physics beckoned. But, having graduated from University College London in 1949, Gosling found himself limited in his options. Edward Andrade was the head of the Physics Department, and if Gosling had stayed on at University College, he would have been bound by Andrade's interests in viscosity and this "didn't appeal." Instead, he was tempted by developments across town at King's College, rivals-in-chief to his own alma mater (Box 1), where John Randall (Box 2) had recently taken the Wheatstone Chair of Physics. Instead of being deterred by the rivalry, Gosling impishly thought to himself that it would be "rather fun" to join Randall's laboratory.

\section{Box 1.'The best rag I ever came across'}

To illustrate the level of treachery that his move from University College to King's College might have been perceived as,

Gosling relates a practical joke that took place in the 1930s: "The engineers at University College got into the front reception hall in King's and cut a hole in the belly of Reggie the Lion, who's their mascot, and filled it with rotten vegetables that they'd got from Covent Garden, and sealed it up and painted it and put it back where it was, which was on a special plinth above the entrance doors. And it was weeks while the beadles looked for the source of the smell, and that was I think the best rag that I ever came across."

\section{John Randall: the unsung hero of the double helix}

If there's one message that Raymond Gosling would like you to take away from this article, it is that the role of John Randall in the pursuit of the double helix cannot be overstated, and that Randall has lamentably not been adequately credited in most tellings of the story. Gosling feels so strongly on this subject that he recently wrote to The Times to emphasize the point, prompted by an article that had recognized Rosalind Franklin's contribution but that had omitted Randall's.

Randall's motto at the Medical Research Council (MRC) Biophysics Unit that he headed at King's College was 'to bring the logi of physics to the graphi of biology'. This interdisciplinary philosophy was at the time decidedly modern, and his switch from the questions of physics to those of biology was also, according to Gosling, "ahead of the curve". Randall's modernity extended to his respect for female scientists, many of whom he recruited at King's, as exemplified by his long-standing working relationship with Honor Bell. This facet of Randall's modern outlook was to prove very important with his later recruitment of Rosalind Franklin (Box 2).

"The people in the University and a few other establishments tended to make fun of Randall's approach, his claim that you would need to have different disciplines working together, and they called it 'Randall's Circus'. Now, that's what attracted me in the first place! I heard about this strange bald-headed little man with a Napoleonic complex who was running the circus in biophysics, and it sounded wonderful to me!"

So was it the rebellion that Gosling was attracted to? "Yeah, absolutely!"

Randall's most important legacy was his firm belief that DNA must be the agent of genetic inheritance, a concept not widely recognized at the time (despite good evidence to support it [8]), and his consequent determination to discover the structure of what he considered to be the genetic material. This was Randall's circus, and he was the ringmaster - and the ringmaster masterfully guided his troupe in its quest. 


\section{Box 2. Watson and Crick's key accomplices - willing and unwitting - in the quest for the double helix}

\section{John Randal}

A physicist by background, Randall was "ahead of the curve" in setting his sights on biological questions. He established the MRC Biophysics Unit at King's, where his modern approach translated to interdisciplinary research with an unusually large, for the time, quotient of female scientists. Randall was "autocratic" and had a "Napoleonic complex", and the Unit was very much his "circus". But Gosling has immense admiration for Randall, and believes that his drive and vision were the magic ingredient that led to the double helix discovery, rendering him the great "unsung hero" of the story.

\section{Maurice Wilkins}

A long-standing colleague of Randall at a number of institutions, Wilkins became his right-hand man once recruited to the Unit, where he served as Assistant Director. A dedicated scientist, the "painfully shy"Wilkins guided Gosling's early work at King's. Wilkins had first attempted to study DNA using ultraviolet light techniques, but without much success. One of the two King's articles co-published with Watson and Crick's work in Nature's April 25th 1953 edition described Wilkins' work, together with Alex Stokes and Herbert Wilson, on the structure of DNA. This publication focused on how to interpret X-ray diffraction patterns and on showing that DNA from various species adopts the same structure.

For his contributions to the discovery of the double helix, Wilkins shared the Nobel Prize in Physiology or Medicine for 1962 with Watson and Crick (Box 3).

\section{Rosalind Franklin}

Rosalind Franklin was recruited to King's, where Gosling worked under her, by Randall and was key to obtaining the quality of X-ray diffraction pattern necessary to determine the structure of DNA. She had come to Randall's attention for her work on the properties of coal as part of the war effort. At the time, it was "very unusual" for a woman to have a senior research role at King's, although not unusual in Randall's laboratory (see text), and many outside Randall's circle were taken aback by it.

Franklin was "a very good experimental scientist, as you had to be if you were a woman in those days." She fell out with Maurice Wilkins from the beginning of her time at King's, largely due to a misunderstanding engineered by Randall (see text), and then earned Jim Watson's enmity when she proved a caustic foe in the race for the double helix. Franklin viewed her study of the tobacco mosaic virus, performed at Birkbeck under Bernal after her DNA research, as her life's greatest work.

Franklin, like Gosling, was a Londoner, although Franklin hailed from the affluent neighborhood of Notting Hill, as the daughter of a merchant banker, whereas Gosling had more modest origins in the suburbs.

Franklin died of ovarian cancer in 1958 at the age of 37, nearly five years to the day after the publication of the double helix. It is thought that Franklin's work with X-rays might have contributed to her death. Several years later, Jim Watson included a very negative account of Franklin in his book, 'The Double Helix' [5], but was met with much opprobrium for doing so. A more recent biography by Brenda Maddox has done much to raise the profile of Franklin and to emphasize the importance of her contribution to the double helix discovery [2]. As Nobel Prizes are not awarded posthumously, Franklin was not eligible to be included in the 1962 Nobel Prize shared by Wilkins, Watson and Crick.

\section{Alex Stokes}

Alex Stokes developed mathematical methods for interpreting X-ray diffraction patterns while at King's MRC Unit; without this know-how, Gosling would not have been able to make sense of his DNA data. Stokes was a co-author, with Wilkins and Herbert Wilson, of one of the three articles on DNA structure co-published in Nature on April 25th 1953.

\section{Rudolf Signer}

As with Randall, Gosling considers Signer to be an "unsung hero" of the double helix story. Signer was a Swiss biochemist, based at the University of Bern, who could produce a DNA sample of far superior quality to any other available at the time. Maurice Wilkins obtained such a sample, derived from calf thymus, after Signer generously offered it to all takers at a London lecture.

\section{Lawrence Bragg}

Lawrence Bragg was awarded the Nobel Prize in Physics, together with his father William Bragg, at the tender age of 25, making him the youngest ever recipient of this prize to date. Bragg's Nobel was in recognition for the methodology of studying crystal structures by X-ray diffraction, which the Braggs had developed at the University of Leeds. It was also at Leeds that William Astbury obtained early X-ray diffraction patterns of (non-crystalline) DNA.

By the 1950s, Bragg was serving as the Head of the Cavendish Laboratory at Cambridge, where both Crick and Watson worked under him. Also based at Bragg's Cavendish for a time was Peter Pauling, son to Linus, who leaked information of his father's interest in the question of DNA's structure. A fourth key player to work under Bragg at the Cavendish was the chemist Jerry Donohoe, who set Watson and Crick right about errors they were making in the likely chemical form of DNA's bases.

\section{Linus Pauling}

Pauling is most notable for his work on the nature of the chemical bond and on the secondary structure of proteins, and was one of the most prolific scientists of the 20th Century, in terms of major advances credited to his name.

Pauling began work on the structure of DNA while King's were working on the problem, and Crick and Watson used the specter of defeat at the hands of Pauling - who had beaten Bragg to the alpha-helix and beta-sheet - to goad Bragg into allowing them to restart work on 


\section{Box 2. Continued}

DNA's structure. As an American based in California, Pauling also added an element of transatlantic competition to the race, although Cambridge-based Jim Watson was of course himself also American.

Pauling published a model for DNA's structure in February 1953. However, the model did not come close to the true structure, with the most obvious mistakes being the number of strands - he had proposed a triple, rather than a double, helix - and the location of the phosphates on the interior of the helix.

Pauling is the only person in history to have won two individual Nobel Prizes - these were for Chemistry (1954) and Peace (1962), the latter as a result of his political activism, some aspects of which had famously brought him unwelcome attention from the United States government, in the form of travel restrictions. In part for this reason, Gosling was never able to meet Pauling in person.

\section{Erwin Chargaff}

Chargaff had discovered the 1:1 ratio that existed between the complementary base pairs in DNA, but had not made the leap from that discovery to the rules of base pairing. Chargaff personally communicated his discovery - dubbed 'Chargaff's rules' - to Watson and Crick, and was "as cross as two sticks" not to be included in Watson's book.

Originally from the present-day Ukraine, and having spent time at various European research institutions, Chargaff relocated to New York to escape the rise of Nazism. It was here, at Columbia University, that he determined 'Chargaff's rules'.

\section{Maurice Wilkins stays awake}

After spending a year simultaneously studying zoology at Birkbeck and working as a medical physicist at Middlesex Hospital, prompted by Randall's insistence that he first learn some biology, Gosling joined the MRC Unit as a PhD student. At the outset, he worked alongside Maurice Wilkins (Box 2), another physicist-cum-biologist, and a veteran of the Manhattan Project racked with feelings of guilt. Wilkins and Gosling used ram's sperm as a source of DNA, following Randall's idea that “ram's sperm have very flat heads - unlike human sperm, which is like a rugby football", the benefit of which was that "the long chains must lie in the plane of a ram's sperm head." But Gosling's attempts to obtain X-ray diffraction patterns from these sperm did not meet with much success.

It would take a series of what Gosling describes as "serendipitous" events to bring about a change in their fortunes ("most of my life has been beset or encouraged by serendipitous acts," he says). There happened to be one man who could produce a sample of DNA of far superior quality to that produced by any other laboratory, and that man was Swiss biochemist Rudolf Signer. By one or two strokes of luck, Gosling managed to obtain a fair quantity of this DNA: "Signer gave a lecture at the Royal Society on this method that he'd developed to separate out the DNA from the nuclear protein and so produce high molecular weight pure DNA. Signer asked at the end of the lecture if anybody would like some of this material, and he had a specimen tube full of this freezedried material. Only two people put their hand up. I'm glad to say that Maurice was awake enough to put his hand up!"

Was that often not the case? "It was often not the case! He rushed down to the front and got half of all there was, which turned out to be very necessary."
Initially, Gosling only wanted to use Signer's DNA as a control to determine which of six methods he had devised for making ram's sperm lie flat was most successful. Wilkins had "a steady hand enough to pull fibers of 5 to $10 \mu \mathrm{m}$. Maurice pulled by wrapping them round a paperclip and then sort of - very scientific! pushing it open to make them taut. I managed to get him to produce at least 35 , so this is a 35 fiber specimen. And little blobs of LePage's cement, priced 6d in Woolworths down The Strand, pulling the fibers together. Very scientific!"

The act of pulling the fiber orientated the molecules along the fiber axis, akin to the orientation that flattening ram's sperm was aiming for. Gosling took the fibers from the Signer sample to the basement of the Chemistry Department, which housed a Raymax X-ray tube. "The first thing I produced was even fuzzier than my ram's sperm! Randall was most amused, and he was delighted to be able to point out that I'd missed a trick because the material that was in my DNA was largely carbon, nitrogen and oxygen, which was just the same as the atoms in the air inside the camera." The result was a diffuse backscattering of X-rays, which fogged the film, and so Gosling was instructed to displace all the air with hydrogen. And this is where the next piece of serendipity steps in.

\section{Serendipity, my dear Watson!}

"This Raymax tube was already in a frightening place, it was three floors below the ground level, which was the level of the Thames, about 50 yards away, because it was the basement of the Chemistry Department. And it was lead-lined so that the X-rays should be shut in because there were various lecture theatres nearby. So having realized that I needed to keep a watchful eye on the amount of hydrogen I was filling the room up with - so 
that I wasn't going to blow myself up and repeat the Hindenberg Disaster - I bubbled the hydrogen through water to help judge when the camera had been swept clean of air. It just so happened that this produced enough water vapor in the camera to be taken up by the fibers and produce crystallites. It turns out that freezedried DNA from Signer's preparation would form microcrystallites in a humidity of $92 \%$, and that was by serendipity alone that I just hit that value."

Gosling is in no doubt that this was "the most exciting thing that's happened to me before or since!" He can still remember the moment clearly: "standing in the dark room outside this lead-lined room, and looking at the developer, and up through the developer tank swam this beautiful spotted photograph, you are familiar with them now I'm sure. It took 90-something hours to take the photograph, again, pot luck. But it really was the most wonderful thing. And I knew at the time that what I'd just done was to produce a crystalline state in these fibers, and if then the DNA was the gene material, I must be the first person ever to make genes crystallize."

Did Gosling realize at that moment that it would from then onwards just be a matter of time, that the structure of DNA was now in his grasp? "Yes. Yes, that was why I could truly say it was my 'Eureka!' moment. I went back down the tunnels over to the Physics Department, where Wilkins used to spend his life, so he was still there. Wilkins realized even more certainly than I did that we had just crystallized genes. As with Randall, he was convinced that the DNA was the genetic material, and now he was convinced that the DNA could be made to crystallize. I can still remember vividly the excitement of showing this thing to Wilkins and drinking his sherry by the glass... by the gulpful."

Interestingly, Gosling's account diverges somewhat from that given by Wilkins in his Nobel lecture (Box 3). Another - understandable - omission from Wilkins' lecture is a somewhat unorthodox, and nevertheless essential, contribution he made to Gosling's first X-ray images of crystalline DNA (Figure 2). Gosling had "sealed the conventional camera onto its base and the lid and so forth with vacuum wax and stuff that you used in order to keep air out. This was to keep the hydrogen in, of course. The collimator was made of heavy brass and although I could seal it to the outside of the camera, there was no way I could think of to really prevent the gas coming out of the collimator tube. To my great surprise, when I was showing him how far I had got, this rather shy Assistant Director of the MRC Unit said: 'Try this.' And he pulled out from his pocket a packet of Durex." By a quirky twist of irony, the introduction of condoms to the story occurs after Gosling had ceased working on sperm, having switched to Signer's DNA, which was derived from calf thymus.

\section{Box 3. Serendipity or sagacity?}

Gosling claims here and elsewhere [11] that he was the first person to crystallize DNA purely by a stroke of luck: he had used water to monitor hydrogen and, serendipitously, the humidity absorbed by the DNA fibers from this water resulted in crystallization (see text).

In his Nobel lecture [12], however, Gosling's colleague Maurice Wilkins gives a different version of events: 'One reason for this success was that we kept the fibres moist. We remembered that, to obtain detailed X-ray patterns from proteins, [JD] Bernal had kept protein crystals in their mother liquor. It seemed likely that the configuration of all kinds of water-soluble biological macromolecules would depend on their aqueous environment.'

Does the 'Assistant Director' refer to Maurice Wilkins? "Yes. But he was painfully shy."

But he was such a dedicated scientist that he was willing to risk the embarrassment... "To risk everything, yes, that's right! It was extraordinary, really."

The condom did the trick, and Gosling was able to produce some high quality X-ray images. This is where Jim Watson first enters the picture: "there was a conference in Naples that was on the structure of biologically active molecules. Randall was invited to talk and said that he couldn't, so he sent Wilkins, and Wilkins showed our beautiful picture and said: 'Look boys!' Or rather more... I mean his lectures were as dry as dust, so in a dusty sort of way, he made it clear that they had crystallized the genetic material. Now, Watson was in the audience, and I was told by somebody else who was there that Watson up until then had been doing his usual trick of pretending to read the newspaper while everybody gave of their best results and so forth. And he actually... when the picture came up on the screen in Wilkins' lecture, he actually put his paper down. And so he was convinced then and there, that if the material could be crystallized, then the structure could be found and it was just a short step from one to the other."

Watson, having seen the fruits of Gosling's serendipity, asked Wilkins if he could join the MRC Unit, but was refused "because Wilkins was afraid of him. He's quite scary, old Jim, on full flight." Instead, he approached Bragg (Box 2) at Cambridge's Cavendish laboratory, where - by another stroke of serendipity (Box 4) - he ended up allocated a desk next to Francis Crick. And the rest, as they say, is history...

\section{Rosalind Franklin: a friction engineered by Randall?}

Meanwhile, Randall was not convinced that Wilkins and Gosling would ever learn enough crystallography "to be able to solve this spotty diagram." For this reason, Rosalind Franklin was recruited to the project; Gosling 


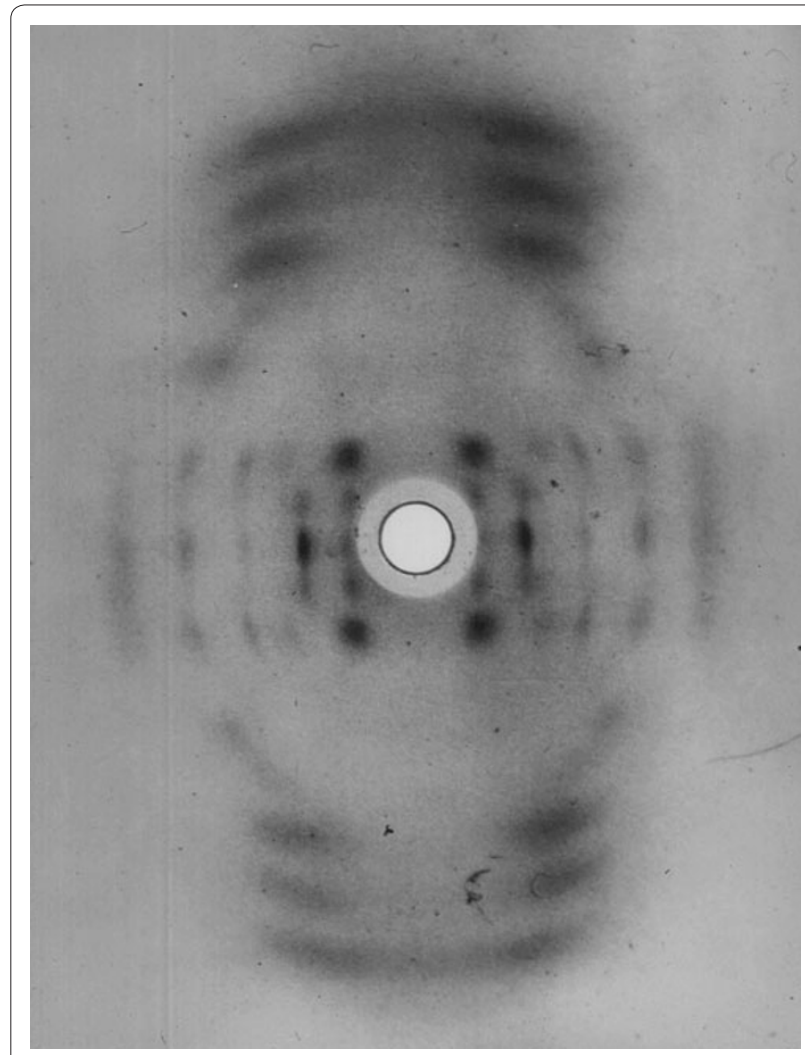

Figure 2. An early X-ray diffraction pattern of crystalline DNA. An example of an early $X$-ray diffraction pattern image of crystalline DNA taken by Ray Gosling at King's College. Later, the arrival of Rosalind Franklin spurred an improvement in the quality of these patterns. (c) Raymond Gosling; reproduced with permission.

believes that her appointment is another key pillar of Randall's contribution to the double helix story, as her experimental talent proved invaluable.

Famously, Franklin and Wilkins enjoyed - or, rather, did not enjoy - a very fractious relationship. Gosling sees it as a "pure personality clash", as well as a very unfortunate misunderstanding, which only came to light many years later. "The whole trouble was that there was a meeting in Randall's office, where Rosalind turned up and Alex Stokes and myself were invited along to meet her, and Wilkins was off somewhere else. In his autobiography, I think he says that he was away in Wales with a new girlfriend. But that was the key to what followed, he wasn't there." At this meeting, Gosling was assigned to work under Franklin, having previously been working with Wilkins.

"It was a very curious thing. Randall actually wrote to Rosalind saying that she would be asked to direct the Xray crystallographic work on the Signer DNA material, and I didn't know that he'd done that." As with Gosling, Wilkins himself was not made aware of this letter until many years later.

\section{Box 4. Watson and Crick: the perfect pairing}

Gosling relates how, having been refused entry to King's, Jim Watson "was nonetheless convinced that he had to learn some basic crystallography, and then he'd be able to find the structure of DNA." He approached Sir Lawrence Bragg and asked to join his Cavendish Laboratory at the University of Cambridge, and was accepted ("you didn't turn down a pair of willing hands which came self-funded.")

Because of the way the space requirements of his workers happened to be at that time, Bragg gave Watson a spare desk next to Francis Crick ("a thoroughly nice man"), who was "already getting Sir Lawrence rather mad because - as Bragg was heard to say several times - the man never stopped talking. And this is true, the man was incredibly wired for looking at exciting new developments." Crick had just come across the argument about whether DNA or protein was the genetic material, and had come to the conclusion it was the DNA. "And here is this pop-eyed chap from America turning up, who is saying that is exactly what it is and the people in King's have got it, and we should build models - that's the way to go."

As with the base pairs they discovered, Gosling considers Watson and Crick to be the perfect complement to one another: Crick's "genius" and Watson's "persistence".

Gosling notes the contrast between the experimentalists at King's and Watson and Crick, who "never did an experiment in their lives, it was all deductive powers of reasoning." Nevertheless, Gosling believes that those powers were very much worthy of the Nobel Prize in Physiology or Medicine awarded to them, alongside Maurice Wilkins, in 1962.

Gosling believes that the misunderstanding was "deliberate" on Randall's part, rather than an unfortunate oversight. When he eventually discovered the truth of the matter, Gosling was "really shocked" because "it was against all Randall's principles as I understood them. Up until then, everybody would freely discuss their work and interact with Wilkins probably more often than interacting with Randall directly."

Perhaps most peculiar in the whole episode is that Randall and Wilkins had known each other for many years, and had been close colleagues at several institutions. So what was Randall's motivation? "He definitely subscribed to the divide and rule principle, as lots of people did. He thought it would make them competitive and improve their work."

Another school of thought might be that Randall did not think Wilkins up to the job of the matter at hand, but did not want to confront him directly about these concerns. However, when this theory is put to him, Gosling is unsure. But what is for certain is that Franklin had very much been told by Randall - "this very dynamic Head of Department" - that she was a post-graduate fellow and it was her research, not Wilkins'. 
"Wilkins came back to the lab after a few days and, you know, said, 'How are you?' and 'What are you doing' sort of thing, and got her back up. It was very unfortunate." Gosling, in the dark as much as everyone else, joined others in attributing this response to a Bolshie streak in Franklin's character, and also had sympathy for Wilkins, having previously worked closely with him. Now that he was Franklin's student, Gosling was very much caught in the middle: "It was terrible, terrible. I spent my life going from one to the other, giving messages, trying to play the peacemaker."

Eventually, the dispute between Wilkins and Franklin resulted in Randall suggesting to Franklin that she had better leave, even though the DNA work was not yet complete - although he was good enough to "fix her up with his old pal [JD] Bernal" at Birkbeck.

Later on, Wilkins was "beset by worry that he had been responsible for not integrating Rosalind into the group" and it very much lingered with him, to the extent that, for the rest of his life, he would frequently ask Gosling whether he had been unkind to her.

\section{The wrong model}

All Hollywood script writers worth their salt know that a successful plot is built around a boy meeting a girl, losing the girl and then winning the girl back. Change a few nouns, and you pretty much have the story of the double helix: Crick and Watson 'discover' the structure, lose the 'discovery' when it turns out to be wrong, and then win back the discovery by coming up with a better model. Where they erred was in rushing to triumphalism with the first, incorrect, model: "we suddenly received a call, in '51 I think it was, from Crick - from Maurice. Crick had got in touch with Maurice to say that he hoped he didn't mind, but they had built - him and Jim had built - a model of DNA as a double helix, following the results that we had deduced in structure 'B'. And would we like to go to Cambridge to see it?"

According to Gosling, it was clear to him then that the King's data, such as it was at the time, had fed into Watson and Crick's model. Nevertheless, Gosling, Franklin and Wilkins, together with their King's colleagues Bill Seeds and Geoffrey Brown, took the Liverpool Street train "with a heavy heart" to Cambridge. But, upon arrival, it was immediately apparent that Watson and Crick had made some elementary mistakes, in both senses of the word.

"We arrived in the lab to be shown the model and to the absolute relief of Rosalind and myself - I don't know about Wilkins, what he thought at the time, because I was dealing with my own thoughts and not observing other people - the boys had built a model with the phosphate linkages going up the middle of the thing, which gave it, of course, rigidity, and so you could hang all the nucleotides and things off the ends of the ionic chain. That must be wrong, because we knew that the water went into that phosphate-oxygen group, and there was an ionic linkage there between the sodium - it was the sodium salt of DNA - and the phosphate group, and you got eight molecules of water going in, quite a lot of water that would go in and come out very easily, as we had shown. So it meant that whatever the structure was, those phosphate groups had to be on the outside. And so we were delighted, and Bragg was embarrassed because it wasn't done to actually work on another man's problem."

Watson and Crick's recklessness, in playing their cards so early, was pounced upon by Franklin, who "tore the model apart point by point." As Gosling notes with some amusement, Crick was later to comment that Franklin's demolition of the model was the only time he ever saw Jim Watson at a loss for words. "And I can believe it!"

So did Franklin deliver her criticism with obvious relish, or did she play it straight? "Oh, no, with obvious relish! She reminded me very much of a particular lady in the University of St Andrews Physics Department that I worked in when I left King's, in which she'd turn up at seminars by new PhD students or the like and she would tear their suggestions apart. 'You're wrong, and you're wrong for the following reasons, one, two, three, four..."

Gosling had, like Franklin, realized instantly that the model was wrong but did not join her in skewering its inadequacies. Why not? "I left it to her. I didn't need to discuss it at all, I mean she was...she was on top of her form! My word, no."

Perhaps the famously negative portrayal of Franklin in Jim Watson's book 'The Double Helix' was payback for this moment? "Yes. Oh, I'd never thought of it, but yes, that's true. The humiliation. He must have felt - that's the word - he must have felt humiliated. Who the hell is this woman telling me... Yes, you can see it more clearly looking back, can't you?"

Rather than focus on Jim Watson's humiliation, however, Gosling was at the time "just happy that it meant that Rosalind and I could go back to the Strand and just get on with doing the mathematics. And it was ours to take as long as we liked."

Watson and Crick's misplaced haste really did seem to have handed the game to King's. When Wilkins reported what had happened to Randall, he was "furious and stormed off to Cambridge to see Sir Lawrence, and Lawrence was apologetic and actually forbade the lads from doing any more work on DNA, and that it was a King's problem and that Crick had plenty to do on hemoglobin and that he should concentrate on getting his PhD."

\section{The American competition}

With the ban imposed upon Watson and Crick, DNA would have remained a King's problem, were it not for 
Caltech's Linus Pauling (Box 2) and, moreover, the inexplicable indiscretion of Pauling's son Peter. Not content with having discovered pretty much everything else going in chemistry and molecular biology, Pauling had turned his attention to the structure of DNA. A physicist by training, Pauling had got under the skin of atoms and molecules with great success to describe the nature of the chemical bond and the secondary structure of proteins, and much else besides. So he seemed like a good bet in the race to discover the structure of DNA.

Pauling's son Peter was at the time based in Cambridge, and somehow managed to leak the news of his father's interest in the question to Jim Watson. The prospect of losing to Pauling, who had already beaten him to the alpha-helix and beta-sheet, was too much for Bragg, and he allowed Watson and Crick to start work on DNA again.

It so happens that the first papers Pauling wrote on the subject actually contained the same mistake made by Watson and Crick, in that the phosphates were on the inside. Further, his proposed structure was a triple, rather than a double, helix $[7,8]$. It was very wide of the mark, but the threat of Pauling's intellectual prowess was not to be underestimated.

Does Gosling believe that Bragg's reaction was justified? After all, a draft manuscript written by Franklin shows that she had already drawn many correct conclusions about DNA's structure, including its double helical nature. Would Pauling have arrived at the model before King's with Cambridge out of the race? "That's the problem. That's the $\$ 64,000$ question I've been asked so many times. 'How long would it have taken you?' And I don't know."

\section{King's loses the race}

Franklin's methodological approach was not that of someone in a race to the prize, but instead favored slow, steady progress. Franklin's skills as a chemist had borne fruit in determining that there were two crystalline forms of DNA, dependent on the humidity; the respective forms at lower and higher humidity were christened by Gosling and Franklin 'A' and 'B'. It was accepted that 'B' would be the in vivo form, due to its formation in humid conditions, and Franklin had taken an exceptionally high quality X-ray diffraction pattern of this form ('photo 51, see Figure 3), which proved invaluable to Watson and Crick. From the King's data, it was clear that 'B' was helical, but this could not be said with certainty for 'A' (Figure 4).

Franklin had set herself the task of deducing the structure of 'A' from first principles, using Patterson functions, and she was having quite some success in doing so. "We were the first people ever to do a cylindrical Patterson. But now nobody does it, because the computer would do it for you in a twink. And so you

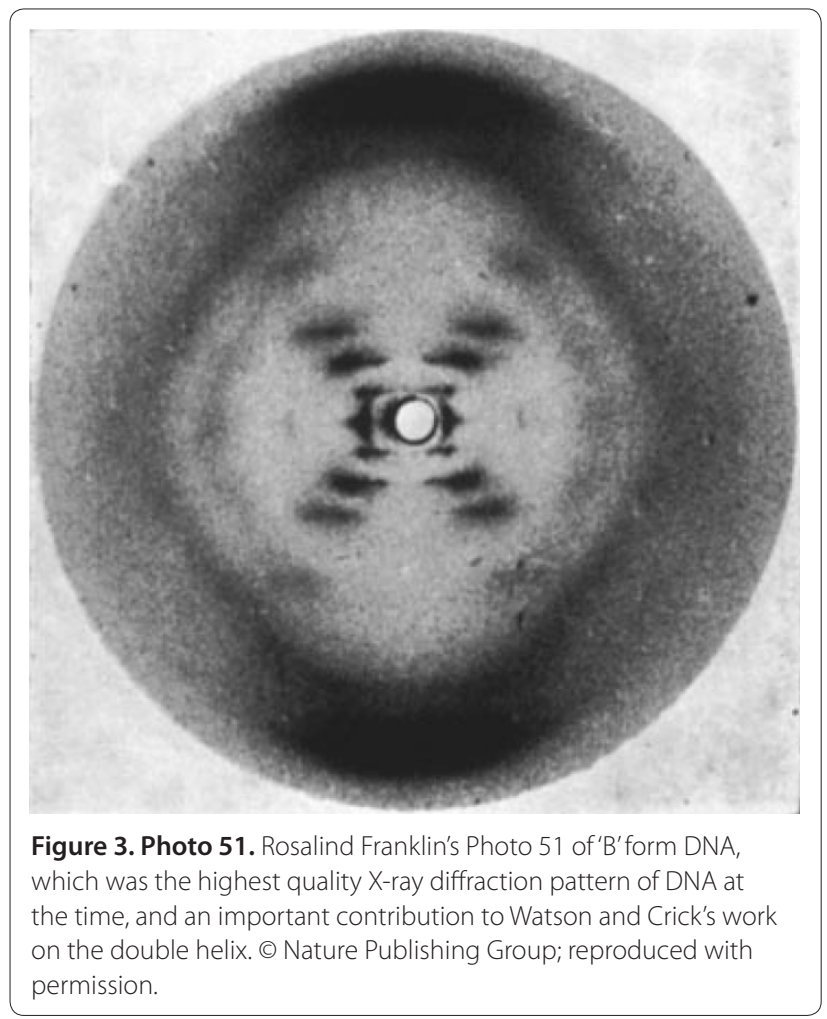

would probably go straight to an atomic density map, rather than vectors."

But why the focus on 'A', given that this was known not to be the biologically relevant form? "Well, that's hindsight, isn't it. Her answer would have been, 'we've got over 100 diffraction spots, so we can do all the mathematics of the Patterson function." Such data were not available for 'B', and Franklin's preference for sticking to first principles, and aversion to playing about with models and "guesswork", was the deciding factor.

Another obstacle for Gosling was his ignorance of space groups. "Alex Stokes (Box 2) had taught me enough crystallography that I had been able, before Rosalind was even appointed, to index the spotty picture that I had produced, and find the unit cell and therefore the symmetry that the molecule must exhibit. I got the space group right, I got all the major indices right. But what I didn't realize was that the $\mathrm{C} 2$ space group meant that there must be a dyad axis perpendicular to the fiber axis. The density values, which determine how many strings of the molecule are per unit cell, could in our case be two or four, and we were getting an answer for the density, which was a bit difficult to measure, between two and three. Now Crick realized immediately from my unit cell data that there must be a dyad axis and therefore, if this double diamond was showing a helical pattern, it meant there was a double helix." 


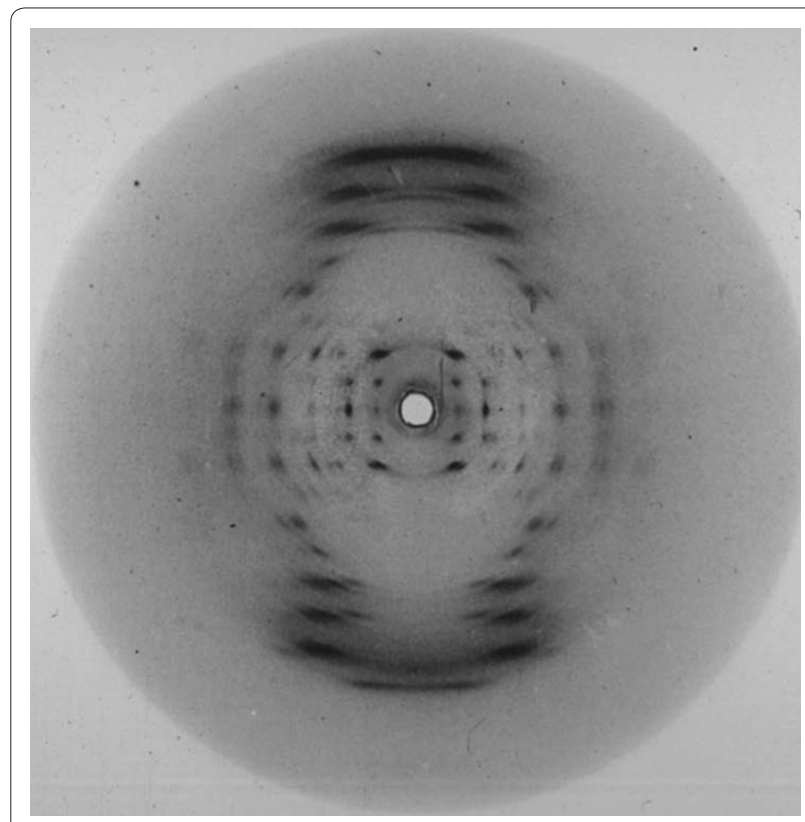

Figure 4. 'A' form DNA. An example of an X-ray diffraction pattern obtained by Rosalind Franklin and Raymond Gosling from 'A' form DNA, which is distinct from the ' $B$ ' structure predominately found in vivo. Before embarking on the determination of the ' $B$ ' form structure, Franklin and Gosling had set out to determine the structure of ' $A$ ' form DNA from first principles. @ Raymond Gosling; reproduced with permission.

The reason Crick knew all about this space group was that he was studying, under Bragg, the structure of hemoglobin, which just so happens to share the same space group. So another bit of serendipity? "Absolutely."

The slow pace at King's was no match for the fury of Watson and Crick's efforts, and so it came to pass that Gosling, Franklin and company were called up to Cambridge a second time...

\section{That 'eureka!' moment}

"We went up, saw the structure, we came back to King's and looked at our Pattersons, and every section of our Pattersons we looked at screamed at you, 'double helix!' And it was just there! - once you knew what to look for. It was amazing."

When Gosling saw this second structure - the double helix we are now so familiar with - for the first time, was it as obvious to him that this model was right as it had been that the first model was wrong? "Absolutely. Absolutely, because it was so elegant. And it also explained the diffraction pattern as being such a clear double helix because the phosphate groups were on the outside, the sodium then was ionically bonded to the phosphorous, and the eight molecules of water went into the same group. So you got this enormous scattering power, due to the electronic number of oxygen, nitrogen and carbon."
It wasn't just the phosphates on the outside that made the model so convincing, but also the "stuff in the middle." For one thing, it made a lot of sense that the identities of the nucleotides could be changed without impacting on the overall structure. For another, the nucleotides' "stair rods looked identical to the X-rays because of the way they were bonded." More importantly, Watson and Crick took Chargaff's (Box 2) finding that "no matter which DNA he studied, there was always a 1:1 ratio of adenine to cytosine, and guanine to thymine, and that meant that these were identical" and incorporated it into the model in the form of complementary base pairing. With this seemingly simple rule, suddenly "the solution to DNA's reproductivity was so simple."

Chargaff's ratio was already in the public domain, before Watson and Crick's model was unveiled, but "no one had made the connection" that this meant the DNA structure would rely on complementary base pairing, nor that this "was necessary to explain how the DNA replicated."

So, given that the double helix and all its features were already present in Franklin and Gosling's data, but had somehow been opaque to them, perhaps it was a good thing that Watson and Crick worked on their model, even if by surreptitious means, and the injustice really was more the lack of attribution? Gosling agrees. "I think so. We would have, I think, got there eventually. But Crick himself has said, and Wilkins has agreed with him, that if they hadn't built the model, we would have got there at King's, but not in one fell swoop, that it would have come out in dribs and drabs about the various aspects."

And, as a consequence, history would have been deprived of a singularly exciting moment? "That's right. That 'eureka!' moment, as Jim himself admits to, when you know that that specific pairing is there, and it's in the literature! And then, I can quite sympathize with him in a way, such a very strange feeling. Because I think it was Bernard Shaw who said that very few people are lucky enough to have an original thought in their whole lives. But there I was presented with mine, the crystallization of DNA, as he was, on a plate. Dong! Light bulb!"

Gosling readily offers his admiration for Crick and Watson's achievement: "they'd not only put together a model showing that the DNA was in the form of a double helix, but that it had this dyad axis and that this meant that these stair rods of the nucleotides had to be specifically paired - now that was worth a Nobel Prize."

Similarly, Franklin reacted to this second model with a level of grace to equal the schadenfreude with which she had destroyed the first. "If you look at the BBC 'Secret of Life' documentary, which is absolutely brilliant - it really is a wonderful thing - they have a shot there, which is of course made up, but it has Rosalind Franklin by herself looking at the model in Crick's lab. And Bragg comes in 
and says something like, 'Do you have any regrets...' - or something like that - '...Miss Franklin.' And Miss Franklin apparently said, 'No, we all stand on each other's shoulders.' And that stuck in my mind. Whether she said it or not, I don't know. But that was her attitude that she took when she and I were discussing it."

To her credit, Franklin "absolutely" put science before ego. However, at the time, she was not aware of the extent to which Watson and Crick had based their model upon her data. Does Gosling believe she came to know about this before her death in 1958? "Yes. Oh, she did know about that."

\section{Obscurity and infamy}

Perhaps surprisingly, given the iconic nature of the double helix today, the 1953 discovery did not initially have much impact, as Gosling saw it. An illustration of this might be the difficulty he had finding work following his $\mathrm{PhD}$ - there were no opportunities for him to stay at King's, which he would have gladly done.

"I talked about DNA for about a year after I wrote my PhD because I was convinced that it would only take a year... that the structure of DNA now being known, the ability to control carcinogenic activity within any tissue you like would be available in two or three years' time. And when two or three years came and went, and nobody had shown that you could... 'Alright, so a double helix, so what?"'

Due to Franklin's enforced move to Birkbeck, Gosling ended up writing his thesis away from King's, under her guidance. This annoyed Randall somewhat, as he was "of the old school, who... in those days, nobody but the Professor had PhD research students." Randall's response to the situation was to appoint himself as Gosling's internal viva (thesis defense) examiner, and he roped in Bernal as the external examiner. Oddly, when you consider that the content of his thesis amounted to a not insignificant contribution to the discovery of DNA's structure, the prospect of his viva with Randall "scared the pants off" Gosling. In part, he explains, this was because his studentship had begun by "trying to establish what the problem was", due to the "amorphous" state of biophysics, rather than starting off with a "ready-made problem", as his friends in Ingold's Chemistry Department at University College had done.

Given that his studentship had been under Randall's direction, the idea that Randall would then find fault with Gosling's rationale in the viva is hard to resolve, outside of a Kafka novel perhaps. "Yes! Very Kafkaesque, yes."

But, still, he surely cannot have been too afraid of defending a thesis describing such successful work? "Well, I can tell you, and I'll tell anybody, that the big difference between writing a paper - especially if you have co-authors - is you can always, when the discussion

\section{Box 5. An encounter with JB Haldane}

Gosling believes he has met three geniuses in his lifetime: Francis Crick, JD Bernal and JB Haldane. "Those three, I was lucky to meet. I mean, I don't think there are very many scientists who have the privilege."

He first met Haldane when an undergraduate at University College, but a later encounter was much more memorable.

"JB Haldane came to a conversazione at the Royal Institution, and it was time for the eaties to be dished out, and so I was the one who got the short straw and had to stay by the model in case anybody came to look at it. And there it was, this lovely double helix. And this Haldane shuffled up and started to roll a cigarette, and apparently he used the cheapest possible tobacco and Rizla paper, and made his own, like he was a student. Nowadays, you would have accused him of making a reefer, a joint. But he rolled it, took a few puffs and said, 'Well, now you will have to find an untw... tw......twiddlase.' Because he had an awful stammer, and that I remember vividly. I stood there awestruck, thinking about an untwiddlase! I mean, this was before the concept of telomeres. But he was on it. Incredible man."

gets too heated, say you didn't write that bit, it was him! But with a thesis, you're aware that as you are writing each word, it can be attributed to you. And that's an odd feeling, especially when you know who your examiners are."

Gosling's fear did not end with the anticipation of his viva, but progressed into the examination itself. "Randall and Bernal had obviously had a very good lunch. I went in there at 2 o'clock, and at half past five, they were still going on talking about the origin of life. I was hardly asked a question. The two of them were at it hammerand-tongs. I was terrified. I was just terrified, because I was convinced that Bernal was a genius - one of only three I have met in my life, together with Crick and Haldane (Box 5)."

Having become disillusioned about the failure of the double helix to make much of an impression, Gosling lost interest and drifted away from the field. He had in any case wanted to move closer to his original dream, medicine, and did indeed go on to lead a successful career as a medical physicist (Box 6).

But an unexpected development suddenly cast the double helix in the spotlight, and spawned a legend that solidified its place in popular culture. Jim Watson wrote a book. In Gosling's eyes, "that's what did it" for the double helix. And that's where Gosling's praise for Watson's book - 'The Double Helix' [5] - ends.

"That book is a novel. A very successful novel, but it is a novel. Wilkins and Crick wrote to Harvard saying they should not publish this book, and they didn't." But someone else did.

Another unhappy reader of 'The Double Helix' was Max Perutz. While Watson and Crick obtained some of 


\section{Box 6. Gosling after DNA}

After the initial double helix data had been published, Gosling and Franklin finished up their research into the structure of DNA with another article in Nature [13]. Gosling continued to work in crystallography for a few years, focusing on the structure of nucleotides, but spent most of his career as a medical physicist, developing devices for the study and diagnosis of atherosclerosis.

The idea to perform this work originated from a discussion he had while based at the University of the West Indies. "Again, a somewhat serendipitous situation developed, in that I got to know very well indeed the senior lecturer in morbid anatomy. He wanted an explanation as to why the fatty plaques should develop in arteries where the blood was moving fastest, that this was an anomalous situation, and all of the work that was being done on atherosclerosis - on atherogenesis, if you like - at that time was being done by biochemists. And he said, surely, isn't there a big hole here for someone who is a biophysicist to look at the characteristics of the pulsatile flow, and that must play a part in the formation of these plaques."

Gosling began the project while on a sabbatical back in Randall's laboratory at King's and, while there, Randall persuaded him to change tack. "One day in my little lab, Randall appeared. And he had this terrifying habit of doing just that. I mean, he walked around with hush puppies and you couldn't hear him coming, and suddenly you were in an empty lab and then the next thing you know, he's at your elbow. Terribly dangerous! But what he said was illuminating. He'd come down to find me because he wanted me to stop building glass tubes with lumps inside, because if I did, and if I was successful in replicating the conditions, all that would happen is that some bloody physiologist would come along and pooh pooh the whole thing because it was not like the in vivo state, and that what I ought to do is to build an animal model and observe it directly in a living situation. And then he disappeared."

Gosling took Randall's advice and, when he returned to Jamaica, switched to working on cockerels, which turned out to be the best animal model available. Later, he continued his work on atherosclerosis at Guy's Hospital, London, where he developed ultrasound devices for the analysis and diagnosis of atheromatous plaques. This phase of his career included an important discovery.

"As the lumps developed, so it changed the elasticity of the artery wall. As you know, you get hardening of the arteries as they build up with atheromatous plaques, but we were able to show that, before that happens, they get three times more distensible, which was an unlooked for, unknown thing - counterintuitive."

Gosling found the direct impact he could see his work making in medical physics more satisfying than fundamental biology, and he also preferred the more steady rate of progress to the manic ups and downs of his years as a crystallographer. His time at King's, therefore, was a preamble to a rewarding and successful career that led Gosling in a very different direction to his fellow actors in the double helix story.

Now retired, Gosling's contribution to science has been recognized in the form of election as a Fellow of King's College and the award of a DSc from the University of the West Indies. Inexplicably, Gosling has never received recognition in the Queen's honors system from the British government, although he was invited to meet Prime Minister Tony Blair at Downing Street in honor of the double helix's 50th anniversary.

the King's data through Crick's friendship with Maurice Wilkins ("Innocently. Because he'd always discussed his work, as Crick had with him, from their undergraduate days."), other data came from a progress report submitted to the MRC, which Watson had obtained from Perutz.

"I actually had a letter that I can no longer find from Perutz saying that he wanted me to be assured that he did not rush down the corridor waving the MRC report containing our contribution about the size and shape of the molecule. It's true they had actually got it from him. But the way Watson tells it, it's sort of Archimedes getting out of the bathtub again, you know."

Key for Crick and Wilkins was their dismay at the portrayal of Rosalind Franklin, which amounted to what you might describe as an ad hominem character assassination, and a wildly inaccurate one at that. Worse still, Franklin had died of ovarian cancer several years earlier, and so was not able to defend herself. Was Gosling also angry about how she had been portrayed? "Yes. Very much so."

But he is gratified that many people rose to Rosalind's defense ("her part in it now is if anything overplayed!"), and in particular that Brenda Maddox's "first class" biography of Franklin was able to set the record straight [2]. Unwittingly, Watson is responsible for the widespread admiration with which Franklin is viewed today, which is to a large degree a reaction to his book.

How did Gosling feel about his own portrayal in 'The Double Helix'? Was he concerned that his role had been underplayed? "No, not really. But I felt that Watson was so busy criticizing poor Rosalind that he didn't mention and give credit to the work of Alex Stokes and Wilkins and myself. And Randall."

Despite his strong reservations about 'The Double Helix', Gosling acknowledges that Watson has much to be complimented for. "He is very precocious, he is one year younger than me, which annoys me - ha! - and he is without doubt a very lively mind and his ability to spot that specific pairing was worth the Nobel Prize."

\section{Reconnecting with DNA}

As mentioned previously, Gosling's subsequent career deviated from biology (Box 6), and he didn't follow the progress of molecular biology during this time ("not at all!"). This scientific realignment proved problematic on one occasion during his tenure at the University of the 
West Indies, when he was asked to deliver a lecture to the Trinidad campus on what his discovery was leading to. "I hadn't the foggiest! So I had to bone up, and that was incredible."

Asked jocularly whether he contacted Francis Crick for assistance, Gosling replies that, actually, he did! "Well, yeah, I did have a conversation with Francis. And it was... the whole thing was fascinating, I mean to look into this new world."

When Gosling hears of developments that have come from his work at King's, does he feel connected to it? "No, I feel detached, I really do - it's gone way ahead of where I was. But I realize that I don't go to the literature enough to say that I have kept up."

The 50th anniversary of the double helix reignited the world's interest in Ray Gosling, and suddenly he was invited to events alongside Nobel laureates and other giants of the molecular biology world - most of whom he had never met before, nor even been aware of their work. Gosling was particularly taken with Alec Jeffreys ("a very nice chap") and Paul Nurse ("a very witty fellow indeed"), and was "very flattered" when Nurse invited him to contribute a brief memoir of the double helix to a time capsule for The Francis Crick Institute.

Have any DNA-based developments caused him concern, in the same vein as the conflicted feelings felt by Wilkins and some other alumni of the Manhattan Project? "No. But I do very much feel that I can't stress enough the critical stage we're at. Up until now evolution has occurred spontaneously, set in motion in all sorts of ways. And what is happening now is that our species are the first ever to have their hands on the levers controlling evolution. If you are a pessimist, you would say the glass is half empty, and you would think it's rather a sinister situation. So you have to take an optimistic point of view, at least I think you do."

Work on transgenic animals has made a strong impression on Gosling (he highlights the example of so-called spidergoats), as has the notion of an embryo with three genetic parents, in which maternal chromosomes and mitochondrial DNA originate from different individuals.

Returning to his favorite theme of Randall, Gosling recalls how in later years the ringmaster of the double helix discovery focused his work on cilia. "Randall again was ahead of his time, wasn't he? In concentrating on the cilia. Isn't that fascinating? How long's the old boy been dead? '84, gosh. He would have been so pleased, wouldn't he..."

Published: 25 April 2013

\section{References}

1. Watson JD, Crick FH: Molecular structure of nucleic acids; a structure for deoxyribose nucleic acid. Nature 1953, 171:737-738.

2. Maddox B: Rosalind Franklin: the Dark Lady of DNA. London: HarperCollins; 2002.

3. Franklin RE, Gosling RG: Molecular configuration in sodium thymonucleate. Nature 1953, 171:740-741.

4. Wilkins MHF, Stokes AR, Wilson HR: Molecular structure of deoxypentose nucleic acids. Nature 1953, 171:738-740.

5. James D. Watson: The Double Helix: a Personal Account of the Discovery of the Structure of DNA. Weidenfeld \& Nicolson; 1968.

6. Doolittle WF, Fraser P, Gerstein MB, Graveley BR, Henikoff S, Huttenhower C, Oshlack A, Ponting CP, Rinn J, Schatz M, Ule J, Weigel D, Weinstock G: Sixty years of genome biology. Genome Biol 2013, 14:113.

7. Erwin Schrödinger: What Is Life? SI: Cambridge UnivPress; 1944

8. Avery OT, Macleod CM, McCarty M: Studies on the chemical nature of the substance inducing transformation of pneumococcal types: Induction of transformation by a desoxyribonucleic acid fraction isolated from pneumococcus type III. J Exp Med 1944, 79:137-158.

9. Pauling L, Corey RB: A Proposed Structure For The Nucleic Acids. Proc Natl Acad Sci USA 1953, 39:84-97.

10. Pauling L, Corey RB: Structure of the Nucleic Acids. Nature 1953 171:346-346.

11. Gosling R: The Genesis of a Discovery: First Steps. GEN 2013, 33:29-31, 45.

12. Nobelstiftelsen: Nobel Lectures: Physiology or Medicine, 1942-1962; Including Presentation Speeches and Laureates' Biographies. Amsterdam \&c: Elsevier for the Nobel Foundation; 1964

13. Franklin RE, Gosling RG: Evidence for 2-chain helix in crystalline structure of sodium deoxyribonucleate. Nature 1953, 172:156-157.

doi:10.1186/gb-2013-14-4-402

Cite this article as: Attar N: Raymond Gosling: the man who crystallized genes. Genome Biology 2013, 14:402. 